\title{
Effects of natural flavones on membrane properties and citotoxicity of HeLa cells
}

\author{
Tatiana Herrerias, ${ }^{1}$ Alexandre A. Oliveira, ${ }^{2}$ Maurício L. Belem, ${ }^{2}$ Brás H. Oliveira, ${ }^{2}$ \\ Eva G. S. Carnieri, ${ }^{1}$ Sílvia M. S. C. Cadena, ${ }^{1}$ Guilhermina R. Noleto, ${ }^{1}$ Glaucia R. Martinez, ${ }^{1}$ \\ Maria B. M. Oliveira, ${ }^{1}$ Maria E. M. Rocha ${ }^{*}, 1$
}

\author{
${ }^{1}$ Departamento de Bioquímica e Biologia Molecular, Universidade Federal do Paraná, Caixa Postal 19046, \\ 81531-990 Curitiba-PR, Brazil, \\ ${ }^{2}$ Departamento de Química, Universidade Federal do Paraná, Caixa Postal 19081, 81531-990, Curitiba-PR, Brazil.
}

\begin{abstract}
RESUMO: "Efeitos de flavonas naturais em propriedades de membranas e em citotoxicidade de células HeLa". O objetivo deste estudo foi avaliar se eupafolina e hispidulina, flavonas extraídas do Eupatorium littorale Cabrera, Asteraceae, possuíam a capacidade de alterar propriedades das membranas biológicas e promover efeitos citotóxicos. Eupafolina (50-200 $\mu \mathrm{M}$ ) reduziu em aproximadamente $30 \%$ a velocidade e amplitude do inchamento mitocondrial induzido por valinomicina e $60-100 \%$ o inchamento mitocondrial dependente de substrato. Além disso, eupafolina na dose de $200 \mu \mathrm{M}$ reduziu a transição de permeabilidade mitocondrial em 35\% entretanto, a hispidulina não alterou este parâmetro em todas as doses testadas. A avaliação da transição de fase dos lipossomas de DMPC com a sonda DPH demonstrou que ambas as flavonas afetam a fase gel e fluida. Quando lipossomas de membranas mitocondriais e a sonda DPH-PA foram utilizados, houve aumento da polarização de fluorescência promovido pela hispidulina. Eupafolina e hispidulina, na dose de $100 \mu \mathrm{M}$, promoveram 40\% de redução da viabilidade de células HeLa em 24 h. Nossos resultados sugerem que eupafolina e hispidulina têm efeitos citotóxicos que podem ser explicados em parte pelas alterações promovidas por estas flavonas sobre propriedades de membranas biológicas e sobre a bioenergética mitocondrial.
\end{abstract}

Unitermos: Eupafolina, hispidulina, células HeLa, inchamento mitocondrial.

\begin{abstract}
The aim of this study was to determine whether eupafolin and hispidulin, flavones extracted from Eupatorium littorale Cabrera, Asteraceae, have the ability to change properties of biological membranes and promote cytotoxic effects. Eupafolin (50-200 $\mu \mathrm{M})$ decreased approximately $30 \%$ the rate and total amplitude of valinomycin induced swelling and $60-100 \%$ the energy-dependent mitochondrial swelling. Moreover, eupafolin $(200 \mu \mathrm{M})$ reduced 35\% the mitochondrial permeability transition, and hispidulin did not change this parameter in any of the doses tested. The evaluation of phase transition of DMPC liposomes with the probe DPH demonstrated that hispidulin and eupafolin affect gel and fluid phase. With mitochondrial membrane as model, hispidulin increased the polarization of fluorescence when used DPH-PA probe. Eupafolin and hispidulin $(100 \mu \mathrm{M})$ promoted a reduction of $40 \%$ in cellular viability of HeLa cells in $24 \mathrm{~h}$. Our results suggest that eupafolin and hispidulin have cytotoxic effects that can be explained, in part, by alterations promoted on biological membranes properties and mitochondrial bioenergetics.
\end{abstract}

Keywords: Eupafolin, hispidulin, HeLa cells, mitochondrial swelling.

\section{INTRODUCTION}

Flavonoids are compounds of vegetal origin present in many medicinal plants and foods. They may affect many cellular functions including growth, differentiation and proliferation (Weng et al., 2005; Chen et al., 2005; Rusak et al., 2005) and they also have antioxidant properties (Torel et al., 1986). However, many flavonoids, especially those with catechol ring, have pro- oxidant effects and promote inhibition of mitochondrial respiration (Hodnick, 1986).

We have studied the biological effects of eupafolin (6-methoxy 5,7,3',4'-tetrahydroxyflavone) (1), and hispidulin (6-methoxy-5,7,4'-trihydroxyflavone) (2). These flavones were extracted from Eupatorium littorale Cabrera, Asteraceae, a shrub of up to $1 \mathrm{~m}$ high, common in many parts of Brazil, but very little is known about their chemistry (Oliveira et al., 2001). These flavones are also 
found in several others plants as: Baccharis trimera (Soicke \& Leng, 1987), Artemisia vulgaris, (Jun et al., 1998) and Arnica montana L (Santos et al., 1998), all widely used by Brazilians for treatment of various diseases, however, little is known about its effects on mitochondrial bioenergetics and cytotoxic properties. Eupafolin had demonstrated antioxidant properties (Sanz et al., 1994; Kim et al., 2002) and anti-inflammatory activity (Sala et al., 2000). Hispidulin had promoted inhibition of human platelet aggregation (Bourdillat et al., 1988) and cytotoxicity in nasopharynx human carcinoma cells (Kupchan et al., 1969).<smiles>[R]c1cc(-c2cc(=O)c3c(O)c(OC)c(O)cc3o2)ccc1O</smiles>

We have shown that eupafolin and hispidulin are able to inhibit enzymes of the mitochondrial respiratory chain (Dabaghi-Barbosa et al., 2005; Herrerias et al., 2008); however, the mechanisms involved in this action are not clear. Considering the potential therapeutic significance of these effects, it becomes important a better understanding of their mechanism of action. In this study, we performed assays of mitochondrial swelling and analysis of fluidity of natural and artificial membranes to evaluate the interaction of eupafolin and hispidulin with the mitochondrial membrane in order to clarify if this interaction could be involved in the previously observed effects of these flavonoids on mitochondrial bioenergetics. Also, we evaluated the cytotoxic effect on human cervix adenocarcinoma cell line (HeLa) and discussed its relationship with the effects in biological membranes.

\section{MATERIAL AND METHODS}

\section{Chemicals}

Bovine serum albumin (BSA), valinomycin, rotenone, HEPES, EDTA, dimyristoylphosphatidylcholine (DMPC), sodium glutamate and sucrose were acquired from Sigma (St. Louis, MO, USA). The 1,6-diphenyl-1,3,5hexatriene (DPH) and 3-[p-(6-phenyl)-1,3,5-hexatrienyl] phenylpropionic acid (DPH-PA) were obtained from Molecular Probes. All others reagents were commercial products of the highest available purity grade.

\section{Flavones}

Eupafolin and hispidulin were extracted from leaves of Eupatorium litoralle Cabrera from the Asteraceae family and their structures confirmed as described in Oliveira et al. (2001). The aerial parts were collected in Piraquara (Metropolitan Region of Curitiba-Brazil) and identified by Prof. Olavo Guimarães, the curator of UFPR Herbarium, where a voucher specimen has been deposited (\# UPCB12400) (Oliveira et al., 2001). The flavones were dissolved in dimethylsulfoxide (DMSO) and then further diluted with the assay medium $(25-200 \mu \mathrm{M})$. Solvent controls with DMSO were carried out in each assay.

\section{Animals}

Male Wistar rats (180-200 g) were obtained from the Central Animal House of the Federal University of Paraná (PR, Brazil). The experiments were conducted following the recommendation of the Brazilian Law 6638, $05 / 11 / 1979$ for the scientific management of animals and the procedures were approved by the Institutional Animal Ethics Committee.

\section{Preparation of rat liver mitochondria}

Rat liver mitochondria were prepared according to Voss et al. (1961) with slight modifications. Male Wistar rats were sacrificed by decapitation; liver was immediately removed, sliced in the extraction medium and homogenized three times with a Potter-Elvehjem homogenizer. Homogenates were centrifuged at $2500 \mathrm{x}$ g for $5 \mathrm{~min}$ and the resulting supernatant was further centrifuged at 12500 x $g$ for 10 min. Pellets were suspended in medium and centrifuged twice at $10000 \mathrm{x} \mathrm{g}$. Pellets were suspended in $0.5 \mathrm{~mL}$ medium free of EDTA.

\section{Mitochondrial swelling experiments}

Swelling in energized (Mustafa et al., 1966; Sepalla et al., 1973) or de-energized mitochondria (Moreno \& Madeira, 1990) was monitored by absorbance using a HITACHI (mod U-2001 UV/VIS) spectrophotometer at $546 \mathrm{~nm}$. In both experiments, eupafolin was added to the medium 2 min before initiating swelling measurements.

\section{Mitochondrial permeability transition (MPT)}

Calcium induced-swelling was determined by the turbidity decrease in mitochondrial suspension at $546 \mathrm{~nm}$ in a Hitachi U-2001 UV/VIS spectrophotometer (Bernardi, 1992; Gunter \& Pfeifer, 1990). CsA (1 $\mu$ M) or EGTA (2 $\mathrm{mM}$ ) were used as controls. 


\section{Preparation of membranes}

Dimyristoylphosphatidylcholine

(DMPC) membranes were prepared as described by AntunesMadeira \& Madeira (1984) and Cadena et al. (2001). Native mitochondrial membranes were prepared as described by Antunes-Madeira \& Madeira (1989).

\section{Incorporation of probes and flavonoids into membranes}

Aliquots of 1,6-diphenyl-1,3,5-hexatriene (DPH) or 3-[p-(6-phenyl)-1,3,5-hexatrienyl] phenylpropionic acid (DPH-PA), dissolved in tetrahydrofuran or dimethylformamide, respectively, were added $(1.73 \mu \mathrm{M})$ into membrane suspensions. Flavone $(10 \mu \mathrm{M})$ was then added and incubated for $2 \mathrm{~h}$.

\section{Fluorescence polarization measurements}

Fluorescence measurements were performed with a RF-5301PC spectrofluorophotometer (Shimadzu Scientific Instruments, Inc.), equipped with a thermostatic cell holder. The excitation was set at $365 \mathrm{~nm}$ and the emission at $450 \mathrm{~nm}$ (slit width of excitation and emission $=3$ ). The degree of fluorescence polarization $(P)$ was calculated according to the equation of Shinitzky \& Barenholz (1978). A high degree of polarization $(P)$ represents a high structural order or low membrane fluidity.

\section{Cell viability}

Human cervix adenocarcinoma cell line (HeLa) were obtained from Institute Adolfo Lutz (São Paulo). HeLa cells were grown in MEM medium containing 7.5\% fetal bovine serum and maintained at $37^{\circ} \mathrm{C}$ in a humidified incubator containing $5 \% \mathrm{CO}_{2}$. Cell viability was assessed by MTT staining as described by Reilly et al. (1998).

\section{Protein determination}

Mitochondrial protein was assayed by the method of Lowry et al. (1951), using BSA as standard.

\section{Statistical analysis}

Data are presented as mean \pm SD. Statistical analysis of the data was carried out as analysis of variance and Tukey test for average comparison. Results were considered significant when $p<0.05$.

\section{RESULTS AND DISCUSSION}

\section{Mitochondrial swelling}

The effects of eupafolin on energy-dependent mitochondrial swelling using glutamate as substrate are represented in Figure 1A. Eupafolin promoted a dosedependent decrease in rate and amplitude of swelling and in the shrinkage of the organelles (Figure 1A). At lower concentrations (25-50 $\mu \mathrm{M})$, eupafolin decreased amplitude and velocity of the swelling by approximately $60 \%$, reaching up approximately $100 \%$ at higher doses (75-200 $\mu \mathrm{M})$. We could explain such effects on energized swelling to some extent by enzymatic inhibition (Herrerias et al., 2008) and a possible fluidity reduction of the mitochondrial membrane. Under de-energized conditions, eupafolin (50$200 \mu \mathrm{M}$ ) decreased the initial rate and total amplitude of valinomycin-induced swelling by approximately 30\% (Figure 1B). This result suggests that eupafolin interacts with the lipid bilayer promoting fluidity modifications of the inner membrane.

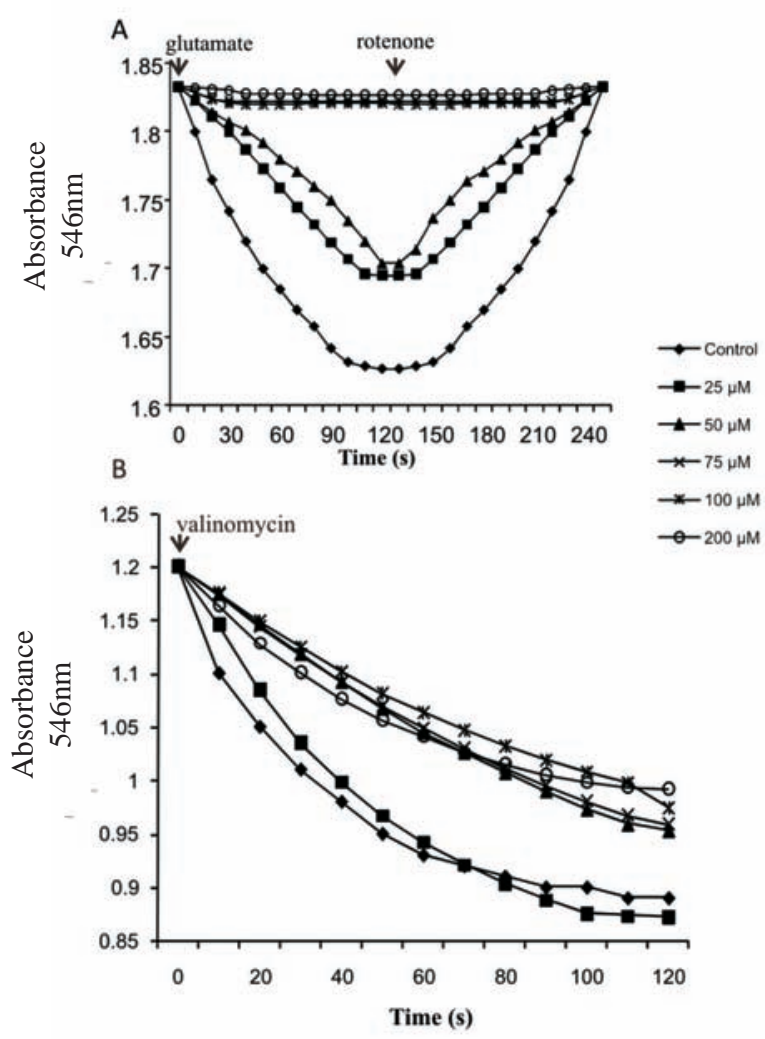

Figure 1. Effect of eupafolin on swelling and shrinkage of rat liver mitochondria (a) energized and (b) de-energized. (A) Mitochondrial suspension (1 mg protein) in a medium containing: 100 mM sucrose, 30 mM Tris-HCl, pH 7.2, 0.5 mM EDTA, 50 $\mathrm{mM}$ sodium acetate. Swelling was induced by addition of 15 $\mathrm{mM}$ of glutamate and shrinkage by addition of $4 \mu \mathrm{M}$ of rotenone in a final volume of $1 \mathrm{~mL}$. (B) Mitochondria suspension (1 mg protein) was incubated in medium containing: $135 \mathrm{mM} \mathrm{KNO}_{3}, 5$ mM HEPES buffer (pH 7.4), 0.1 mM EDTA, $4 \mu \mathrm{M}$ rotenone, 2 $\mu \mathrm{g} / \mathrm{mL}$ antimycin $\mathrm{A}$, the reaction was started by addition of $4 \mu \mathrm{g} /$ $\mathrm{mL}$ valinomycin. In both experiments eupafolin was incubated for 2 min before of the swelling at different concentrations as indicated. Traces are representative of recordings of three independent experiments in triplicate. 


\section{Fluorescence polarization measurements}

In order to evaluate the effects of eupafolin and hispidulin on membrane fluidity, we employed models consisting of liposomes (DMPC) and native membranes (mitochondrial). The probe DPH evaluates interactions of flavonoids with the hydrophobic core, while DPHPA interacts with outer regions of the bilayer. The effect of eupafolin and hispidulin on the cooperative phase transitions of DMPC liposomes with DPH and DPH-PA is represented in Figure 2A and B, respectively. Hispidulin $(10 \mu \mathrm{M})$ increased $P$ values in both, fluid and gel phases with DPH probe (Figure 2A) suggesting that hispidulin decreases the fluidity of DMPC membrane in these conditions. In turn, eupafolin $(10 \mu \mathrm{M})$ modified the phase transition profile of DMPC in a different way. The $P$ values in the gel phase were lower, while they were higher in fluid phase (Figure 2A). The modifications of phase transition profile of DMPC caused by eupafolin and hispidulin did not change the midpoint temperature of thermotropic phase transition (Tm), which remained at $23.5^{\circ} \mathrm{C}$ (Figure
2A). With DPH-PA probe, both drugs affected slightly the thermotropic profile of DMPC liposomes, increasing the $P$ values only at the higher temperatures (32 to $40{ }^{\circ} \mathrm{C}$ ). The Tm value was not altered by flavones (Figure $2 \mathrm{~B}$ ).

For a better correlation with experiments on which were used isolated mitochondria, assays were carried using mitochondrial membrane as model. With DPH probe, eupafolin did not affect the $P$ values, while hispidulin promoted a slight decrease in response to temperature increase (Figure 3A). However, when the probe was DPH$\mathrm{PA}$, hispidulin increased the polarization of fluorescence in relation to control, indicating that it causes a diminution of membrane fluidity. Eupafolin also slightly increased the $P$ values (Figure $3 \mathrm{~B}$ ). Comparing the structure of the flavones used in this study, the difference is the presence of a catechol ring in eupafolin, which could explain, in part, the different interaction with mitochondrial membrane and DMPC liposome (Scheidt et al., 2004). Our results suggest that incorporation of hispidulin preferentially affects the hydrophobic core, and it is in agreement with the hydrophobic characteristic of this flavonoid structure.
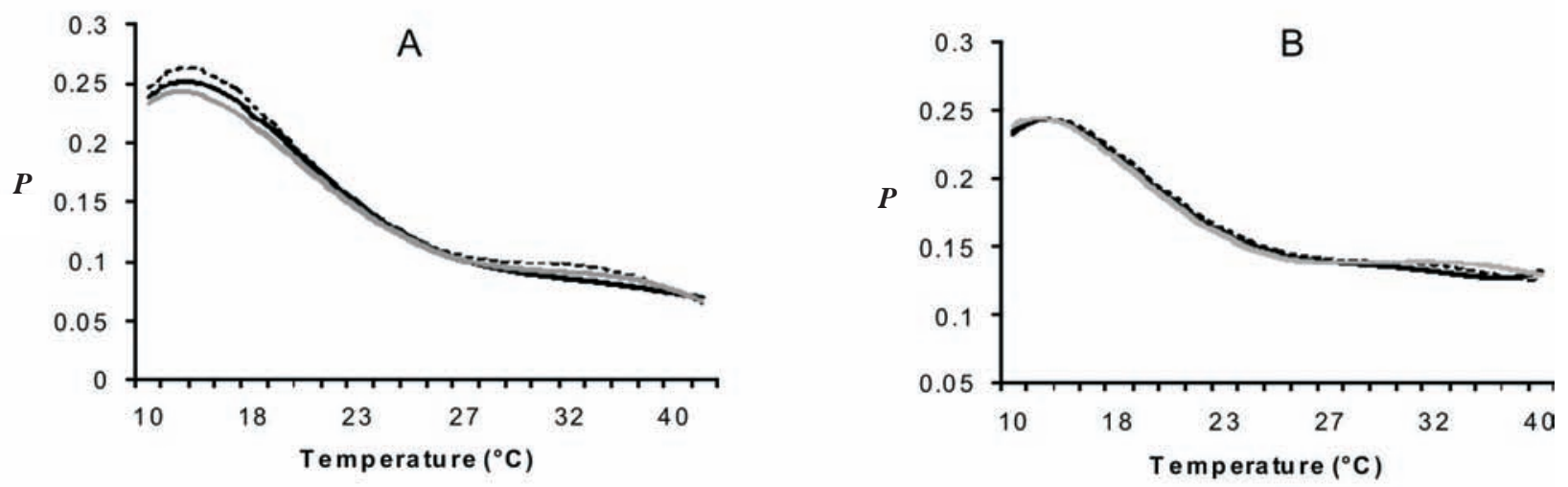

Figure 2. Effects of hispidulin and eupafolin on fluorescence polarization $(P)$ of DPH (a) and DPH-PA (b) in dmpc bilayers as a function of temperature. DMPC membranes (345 $\mu \mathrm{M}$ in total lipid) prepared in $10 \mathrm{mM}$ of Tris-Maleate buffer (pH 7.0) containing 50 $\mathrm{mM} \mathrm{KCl}$ were incubated with eupafolin $(10 \mu \mathrm{M})$ or hispidulin $(10 \mu \mathrm{M})$ or none (control) in a final volume of $3 \mathrm{~mL}$. The excitation was set at $365 \mathrm{~nm}$ and emission at $450 \mathrm{~nm}$. The traces represent typical recordings of three independent experiments.
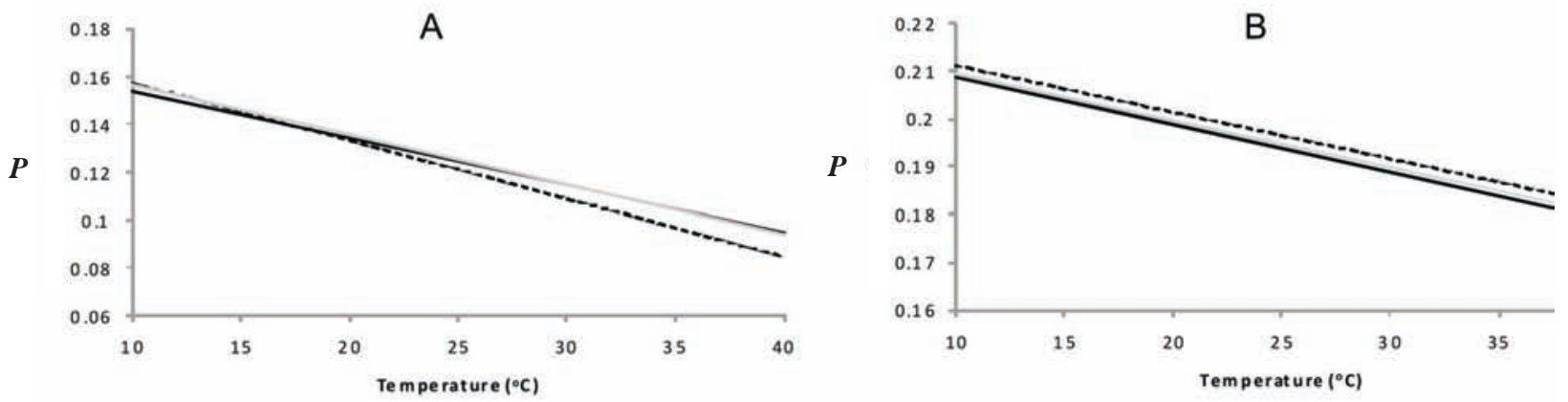

Figure 3. Effects of hispidulin and eupafolin on fluorescence polarization $(P)$ of DPH (a) and DPH-PA (b) in mitochondrial native membranes as a function of temperature. Mitochondrial membranes (345 $\mu \mathrm{M}$ in total lipid) prepared in $10 \mathrm{mM}$ of Tris-Maleate buffer (pH 7.0) containing $50 \mathrm{mM} \mathrm{KCl}$ and $10 \mu \mathrm{M}$ PMSF were incubated with eupafolin $(10 \mu \mathrm{M})$ or hispidulin $(10 \mu \mathrm{M})$ or none (control) in a final volume of $3 \mathrm{~mL}$. The excitation was set at $365 \mathrm{~nm}$ and emission at $450 \mathrm{~nm}$. The traces represent typical recordings of three independent experiments. 


\section{Mitochondrial permeability transition (MPT)}

In this study, we evaluate the effects of eupafolin and hispidulin on swelling induced by calcium. Mitochondrial swelling was observed in the presence of calcium and $\mathrm{Pi}$, in contrast with its full inhibition after addition of the calcium chelator EGTA or the specific pore opening inhibitor CsA (Figure 4A). Eupafolin promoted alteration in the amplitude of the calcium induced mitochondrial swelling only in the highest concentration $(200 \mu \mathrm{M})$ with a reduction of approximately $35 \%$ in this parameter (Figure 4A). Hispidulin did not affect this process in all tested doses (Figure 5B).

\section{Cell viability}

Eupafolin and hispidulin had demonstrated a similar behavior in cellular viability of HeLa cells.

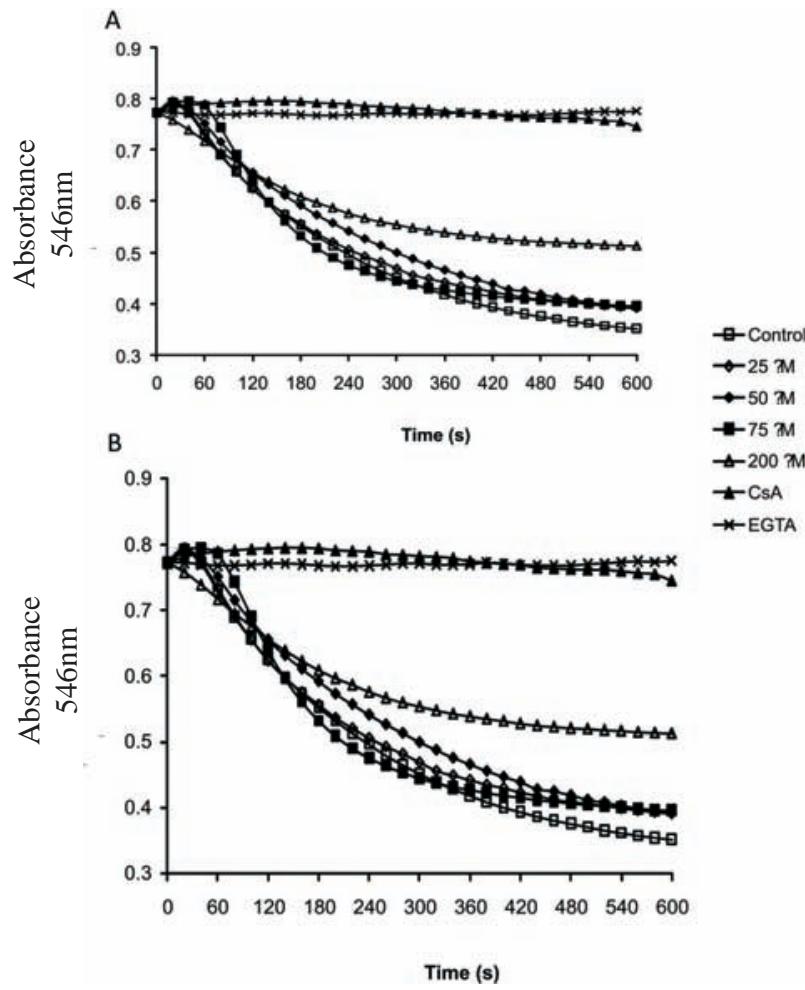

Figure 4. Effect of eupafolin (a) and hispidulin (b) on calciuminduced swelling. Mitochondrial protein (0.3 mg) suspended in a medium containing $250 \mathrm{mM}$ sucrose, $10 \mathrm{mM}$ HEPES, pH 7.2, $0.3 \mathrm{mM} \mathrm{KH}_{2} \mathrm{PO}_{4}, 75 \mu \mathrm{M} \mathrm{CaCl}_{2}, 6 \mu \mathrm{M}$ rotenone, $3 \mathrm{mM}$ succinate supplemented by $1 \mu \mathrm{M}$ CsA, $2 \mathrm{mM}$ EGTA and eupafolin or hispidulin as indicated. Traces are representative of recordings of three independent experiments in triplicate.

They promoted a reduction of approximately $40 \%$ in viability only in the highest dose (Figure 5), what suggest an important anticancer activity effect. These results demonstrate that both flavones, despite the structural differences have similar cytotoxic effects on HeLa cells.
In summary, the results obtained with swelling and fluorescence polarization analysis suggest a fluidity reduction of the mitochondrial membrane promoted by hispidulin and eupafolin. This effect together with the enzymatic inhibitions, which promote an alteration of the electron flux in the respiratory chain and increase the generation of reactive oxygen species (ROS) (Herrerias et al., 2008; Dabaghi-Barbosa et al., 2005), could result in the cytotoxic effects observed in the HeLa cells. These results are important because they contribute to a better understanding of hispidulin and eupafolin action in biological systems and indicate a potential effect against tumoral cells.”

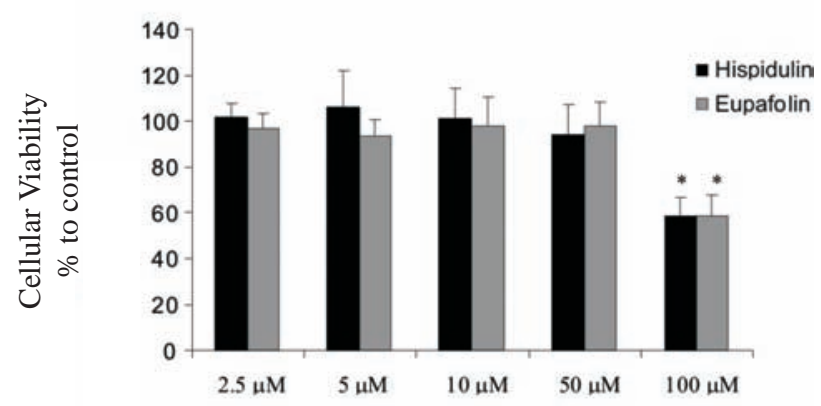

Figure 5. Effects of eupafolin and hispidulin on cellular viability of hela cells. Experimental conditions are described in the Materials and Methods. HeLa cells were plated into 96-well plates and treated with different concentrations of the eupafolin or hispidulin dissolved in DMSO 0.7\% (v/v) as indicated for $24 \mathrm{~h}$ at $37^{\circ} \mathrm{C}$. Each value represents the media \pm SD of three different experiments in triplicate. *Significantly different from the control (100\%), $p<0.05$.

\section{ACKNOWLEDGEMENTS}

This investigation was supported by the Brazilian Research Funding agencies CNPq, Fundação Araucária and CAPES. GRM was also supported by INCT de Processos Redox em Biomedicina-Redoxoma.

\section{REFERENCES}

Antunes-Madeira MC, Madeira VMC 1984. Partition of parathion in synthetic and native membranes. Biochim Biophys Acta 778: 49-56.

Antunes-Madeira MC, Madeira VMC 1989. Membrane partitioning of organophosphorus and organochlorine insecticides and its implications for mechanisms of toxicity. Biochim Biophys Acta 982: 161-166.

Bernardi P 1992. Modulation of the mitochondrial cyclosporin A-sensitive permeability transition pore by the proton electrochemical gradient. J Biol Chem 267: 8834-8839.

Bourdillat B, Delautier D, Labat C, Benveniste J, Potier P, Brink C 1988. Hispidulin, a natural flavone, inhibits human platelet aggregation by increasing cAMP levels. Eur $J$ Pharmacol 147: 1-6.

Cadena SMSC, Carnieri EGS, Echevarria A, Oliveira MBM 2001. Interference of MI-D, a new mesoionic compound, 
on artificial and native membranas. Cell Biochem Funct 20: 31-37.

Chen D, Daniel KG, Chen MS, Kuhn DJ, Landis-Piwowar KR, Dou KP 2005. Dietary flavonoids as proteasome inhibitors and apoptosis inducers in human leukemia cells. Biochem Pharmacol 69: 1815-1827.

Dabaghi-Barbosa P, Rocha AM, Lima AFC, Oliveira BH, Oliveira MBM, Carnieri EGS, Cadena SMSC, Rocha MEM 2005. Hispidulin: Antioxidant properties and effect on mitochondrial energy metabolism. Free Radical Res 39: 1305-1315.

Gunter TE, Pfeifer DR 1990. Mechanisms by which mitochondria transport calcium. Am J Physiol 258: 755-786.

Herrerias T, Oliveira BH, Gomes MAB, Oliveira MBM, Carnieri EGS, Cadena SMSC, Martinez GR, Rocha MEM 2008. Eupafolin: effect on mitochondrial energetic metabolism. Bioorgan Med Chem 16: 854-861.

Hodnick WF, Kung FS, Roettger WJ, Craig WB, Pardini RS 1986. Inhibition of mitochondrial respiration and production of toxic oxygen radicals by flavonoids. Biochem Pharmacol 35: 2345-2357

Jun LS, Yull CH, Maier CGA, Wood AR, Dixon RA, Mabry TJ 1998. Estrogenic flavonoids from Artemisia vulgaris L. $J$ Agr Food Chem 46: 3325-3329.

Kim SR, Park MJ, Lee MK, Sung SH, Park EJ, Kim J, Kim SY, Oh TH, Markelonis GJ, Kim YC 2002. Flavonoids of inula britannica protect cultured cortical cells from necrotic cell death induced by glutamate. Free Radical Bio Med 32: 596-604.

Kupchan SM, Sigel CW, Hemingway RJ, Knox JR, Udayamurthy MS 1969. Citotoxic flavones from Eupatorium species. Tetrahedron 25: 1603-1615.

Lowry OH, Rosebrough NJ, Farr AC, Randall RJ 1951. Protein measurement with the polyphenol reagent. $J$ Biol Chem 193: 265-275.

Moreno AJM, Madeira VMC 1990. Interference of parathion with mitochondrial bioenergetics. Biochim Biophys Acta 1015: 361-367.

Mustafa MG, Utsumi K, Packer L 1966. Damped oscillatory control of mitochondrial respiration and volume. Biochem Bioph Res Co 24: 381-385.

Oliveira BH, Nakashima T, Filho JDS, Frehse FL 2001. HPLC analysis of flavonoids in Eupatorium litoralle. J Braz Chem Soc 12: 243-246.

Reilly TP, Bellevue FH, Woster PM 1998. Comparison of the in vitro cytotoxicity of hydroxylamine metabolites of sulfamethoxazole and dapsone. Biochem Pharmacol 55: 803-810.

Rusak G, Gutzeit HO, Muller JL 2005. Structurally related flavonoids with antioxidative properties differentially affect cell cycle progression and apoptosis of human acute leukemia cells. Nutr Res 25: 141-153.

Sala A, Recio MC, Giner RM, Manez S, Rios JL 2000. Antiphospholipase $\mathrm{A}_{2}$, and anti-inflammatory activity of Santolina chamaecyparissus. Life Sci 66: 35-40.

Santos AC, Uyemura SA, Lopes JLC, Bazon JN, Mingatto FE, Curti C 1998. Effect of naturally occurring flavonoids on lipid peroxidation and membrane permeability transition in mitochondria. Free Radical Bio Med 24: 1455-1461.

Sanz MJ, Ferrandiz ML, Cejudo M, Terencio MC, Bustos G, Gil B, Ubeda A, Gunasegaran R, Alcaraz MJ 1994. Influence of a series of natural flavonoids on free radical generating systems and oxidative stress. Xenobiotica 24: 689-699.
Sepalla AJ, Wikstrom MKF, Saris NEL 1973. Damping of mitochondrial volume oscillations by propanolol and related compounds. In: Chance B, Pye EK, Ghosh AK, Hess B (org.). Biological and Biochemical Oscillators. New York: Academic Press, p. 115-124.

Scheidt HA, Pampel A, Nissler L, Gebhardt R, Huster D 2004. Investigation of the membrane localization and distribution of flavonoids by high-resolution magic angle spinning NMR spectroscopy. Biochim Biophys Acta 1663: 97-107.

Shinitzky M, Barenholz Y 1978. Fluidity parameters of lipid regions determined by fluorescence polarization. Biochim Biophys Acta 515: 367-394.

Soicke H, Leng PE 1987. Characterization of flavonoids from Baccharis trimera and their antihepatotoxic properties. Planta Med 53: 37-39.

Torel J, Cillard J, Cillard P 1986. Antioxidant activity of flavonoids and reactivity with peroxil radical. Phytochemistry 25: 383-385.

Voss OD, Campelo AP, Bacila M 1961. The respiration chain and the oxidative phosphorylation of rat brain mitochondria. Biochem Bioph Res Co 4: 48-51.

Weng MS, Ho YS, Lin JK 2005. Chrysin induces G1 phase cell cycle arrest in C6 glioma cells through inducing p 21Waf1/ Cip1 expression: Involvement of p38 mitogen-activated protein kinase. Biochem Pharmacol 69: 1815-1827. 